\title{
The nonspecific inhibitory effect of synovial tissue extracts on leucocyte migration in vitro
}

\author{
JANE E. MORGAN, N. D. HALL, A. J. COLlINS, AND P. A. BACON \\ From the Arthritis and Rheumatism Research Group, Royal National Hospital for Rheumatic Diseases, Bath, \\ and the Pharmacology Group, University of Bath
}

SUMMARY The leucocyte migration inhibition test (LMT) has been used to search for specific antigens in rheumatoid synovial tissue. Synovial samples were collected from 20 patients with rheumatoid arthritis, from 1 patient with ankylosing spondylitis, and from 1 patient with pigmented villonodular synovitis. Inhibitory material was obtained from all 21 synovia with inflammatory disease but not from the noninflammatory synovium. The tissue extracts generally caused nonspecific migration inhibition when tested against a total of 157 pairs of rheumatoid and control leucocytes. However, occasional samples did induce migration inhibition restricted to either rheumatoid or control cells. The inhibitory factor was shown to be membrane associated and of high molecular weight (greater than $10^{6}$ daltons). The results of this extensive study do not support the conclusions drawn from earlier reports based on smaller numbers of experiments. No evidence was obtained for the existence of specific antigenic material associated with the synovial membrane in rheumatoid arthritis.

The histopathology of rheumatoid synovium suggests that an active immunological reaction is taking place. The tissue is infiltrated by large numbers of lymphocytes and macrophages which may be organised into lymphoid follicles and, rarely, germinal centres. ${ }^{1}$ This is consistent with the ability of rheumatoid synovial tissue to act as an 'ectopic lymphoid organ' with both immunoglobulin synthesis ${ }^{2}$ and lymphokine release. ${ }^{3}$ The importance of lymphocytes in maintaining the chronic inflammatory reaction is supported by the beneficial therapeutic effects of thoracic duct drainage in rheumatoid patients. ${ }^{4}$ The stimulus for this immune reaction has yet to be identified. Infectious agents as sources of exogenous antigen have been sought for many years. However, a careful search for pathogenic organisms in the rheumatoid joint has failed to obtain conclusive evidence that such organisms are reproducibly associated with rheumatoid disease. ${ }^{5}$ An alternative hypothesis suggests that an autoantigen is expressed in rheumatoid synovial tissue, able to provoke an autoimmune reaction and promote chronic inflammation.

Accepted for publication 17 July 1979

Correspondence to Dr N D. Hall, Royal National Hospital for Rheumatic Diseases, Upper Borough Walls, Bath BA1 1 RL.
The search for putative antigens in rheumatoid synovial tissue has been conducted largely with the use of the leucocyte migration inhibition test (LMT) as an indicator system. Using this assay a number of investigators have obtained different results. Rothenberger and Thiele ${ }^{6}$ reported that a crude rheumatoid synovial homogenate used as antigen in the LMT caused the specific migration inhibition of rheumatoid leucocytes, suggesting a delayed hypersensitivity response to a component of rheumatoid synovial membrane. However, they were unable to demonstrate this effect in other experiments using a lymphocyte transformation assay. ${ }^{7}$ The I.MT results with rheumatoid synovial homogenate were confirmed and extended to include simple tissue extracts by Bacon et al. ${ }^{8}$ Migration inhibition was not obtained with homogenates of psoriatic or osteoarthritic synovial tissue. However, crude homogenates of 'normal' (cadaveric) synovium have been reported by other workers to cause migration inhibition of both rheumatoid and spondylitic leucocytes. ${ }^{9}$ Aqueous extracts of both rheumatoid and osteoarthritic synovium have been found to be inhibitory for rheumatoid leucocytes in the LMT. ${ }^{10}$ However, these extracts were also inhibitory for cells from patients with other inflammatory diseases. In contrast, lymphocyte transformation assays 
and skin reactivity were both negative in all patient groups. Previous authors have shown both negative ${ }^{11}$ and positive ${ }^{1213}$ skin reactions to synovial homogenates in rheumatoid patients.

Published reports thus contain confusing and conflicting data on the specificity of the interaction of rheumatoid and nonrheumatoid synovial antigens with leucocytes from both rheumatoid and nonrheumatoid subjects. Therefore we decided to study a larger number of synovial specimens than was used in the above reports and to test these over a range of protein concentrations against leucocytes from a large population of rheumatoid patients together with matched controls. In addition we have attempted to solubilise and characterise inhibitory material from synovial membrane using standard biochemical techniques.

\section{Material and methods}

\section{PREPARATION OF SYNOVIAL \\ HOMOGENATES}

Synovial tissue was obtained from 20 patients with classical or definite rheumatoid arthritis (RA) and from 2 non-RA patients- 1 with ankylosing spondylitis (AS) and 1 with pigmented villinodular synovitis (PVS). All specimens were obtained at surgical synovectomy. Details of these patients appear in Table 1. The synovial tissue was resected without the use of diathermy and was immediately placed in a sterile container at $4^{\circ} \mathrm{C}$ containing either Hanks's balanced salt solution (HBSS) or phosphate buf- fered saline (PBS) containing $2 \mathrm{mM}$ phenylmethylsulphonyl fluoride (PMSF) as a protease inhibitor. The tissue samples were maintained at $4^{\circ} \mathrm{C}$ and were dissected free of fat and cartilage. They were then coarsely chopped with scissors, homogenised (Ilax 1020), and finally sieved through a 60 gauge steel mesh. After standing for 16 hours at $4^{\circ} \mathrm{C}$, the crude suspension was centrifuged at $1000 \mathrm{~g}$ for 20 minutes to yield a supernatant (low spin homogenate). This was stored frozen in aliquots at $-20^{\circ} \mathrm{C}$ before use in the LMT. In some experiments this homogenate was centrifuged at $100000 \mathrm{~g}$ for 60 minutes in order to sediment membrane fragments. Supernatants from this procedure (high spin homogenate) were also stored at $-20^{\circ} \mathrm{C}$ before use.

PREPARATION OF SYNOVIAL ELUATES

Synovial membrane was extracted as described by Marchesi et al. ${ }^{14}$ Briefly, the tissue was homogenised as above, and centrifuged at $1000 \mathrm{~g}$ for 20 minutes. The pellet was washed 3 times with PBS and extracted with EDTA-mercaptoethanol. The eluates were dialysed for 24 hours against $4 \times 5$ litres of PBS at $4^{\circ} \mathrm{C}$ and were then stored at $-20^{\circ} \mathrm{C}$. Protein concentrations were estimated by the method of Lowry et al. ${ }^{15}$

\section{GEL FILTRATION ANALYSIS OF}

SYNOVIAL ELUATES

Protein eluted from synovial tissue as described in the previous section was analysed by gel filtration on

Table 1 Details of patients undergoing synovectomy during the study

\begin{tabular}{|c|c|c|c|c|c|c|c|}
\hline Patient & Sex & Age & Diagnosis & $\begin{array}{l}\text { Duration of disease } \\
(y r)\end{array}$ & $\begin{array}{l}\text { Rheumatoid } \\
\text { factor }\end{array}$ & Site & Drug therapy \\
\hline 1 & $\mathbf{F}$ & 51 & RA & 5 & + & L knee & B \\
\hline 2 & $\mathbf{M}$ & 63 & RA & 8 & + & L knee & $\mathrm{A}, \mathrm{In}, \mathrm{HCO}$ \\
\hline 3 & $\mathbf{F}$ & 27 & RA & 2 & - & $\mathrm{R}$ knee & $\mathbf{A}$ \\
\hline 4 & $\mathbf{F}$ & 37 & RA & 11 & + & L knee & In, $\mathrm{HCO}, \mathrm{Au}$ \\
\hline 5 & $\mathrm{~F}$ & 60 & RA & 11 & + & L knee & A \\
\hline 6 & $\mathrm{~F}$ & 28 & RA & 5 & + & L knee & In, Pr, Pen \\
\hline 7 & $\mathbf{F}$ & 56 & RA & $1 \frac{1}{2}$ & + & R knee & PBZ, Pr \\
\hline 8 & $\mathbf{F}$ & 59 & RA & $29^{2}$ & $\frac{1}{-}$ & $\mathrm{R}$ knee & $\mathrm{Pr}, \mathrm{Cy}$ \\
\hline 9 & $\mathbf{M}$ & 39 & RA & 2 & + & $\mathbf{R}$ thumb & In, Au \\
\hline 10 & $\mathbf{F}$ & 63 & RA & 15 & + & L knee & - \\
\hline 11 & $\mathbf{F}$ & 44 & RA & 6 & + & R knee & In. \\
\hline 12 & $\mathbf{F}$ & 50 & RA & 9 & + & R knee & In, ACTH \\
\hline 13 & $\mathbf{M}$ & 51 & RA & 10 & + & R knee & $\mathrm{B}, \mathrm{N}$ \\
\hline 14 & $\mathbf{F}$ & 68 & RA & 8 & + & L knee & In, A \\
\hline 15 & $\mathbf{F}$ & 67 & $\mathbf{R A}$ & 15 & - & $\mathbf{L}+\mathbf{R}$ elbow & In \\
\hline 16 & $\mathbf{F}$ & 52 & RA & 5 & + & L knee & N, Pen \\
\hline 17 & $\mathrm{~F}$ & 62 & RA & 18 & + & R wrist & In, $\mathrm{Pr}$ \\
\hline 18 & $\mathbf{M}$ & 42 & RA & 4 & + & R knee & $\mathrm{B}, \mathbf{A u}$ \\
\hline 19 & $\mathrm{~F}$ & 41 & RA & 1 & - & R knee & Ib \\
\hline 20 & $\mathbf{F}$ & 54 & RA & 4 & - & R knee & ACTH, $\mathrm{Au}$ \\
\hline 21 & $\mathbf{M}$ & 48 & AS & 27 & - & L knee & K, Pen \\
\hline 22 & $\mathbf{F}$ & 22 & PVS & 1 & - & R knee & - \\
\hline
\end{tabular}

RA = Rheumatoid arthritis. AS = ankylosing spondylitis. PVS = pigmented villonodular synovitis.

Drug therapy: A, aspirin; Au, gold; B, benorylate; Cy, cyclophosphamide; HCO, hydrocortisone; Ib, ibuprofen; In, indomethacin: $\mathrm{K}$ ketoprofen, N, naproxen; PBZ, phenylbutazone; Pen, D-penicillamine; Pr, prednisolone; -, no drugs. 
Ultragel AcA22 (LKB). Eluates were applied to a $90 \times 1.5 \mathrm{~cm}$ column of Ultragel AcA22 and eluted at $4^{\circ} \mathrm{C}$ with $0.01 \mathrm{M}$ phosphate buffer, $\mathrm{pH} 7 \cdot 4$, containing $0 \cdot 15 \mathrm{M}$ sodium chloride. The flow rate was $8 \mathrm{ml} /$ hour, and $4 \mathrm{ml}$ fractions were collected. Selected fractions were pooled and concentrated over a Diaflo PM10 membrane (Amicon) before assay in the LMT.

\section{PATIENTS TESTED}

Peripheral blood was obtained from patients with classical or definite RA. Patients receiving gold compounds, chloroquine derivatives, steroids, or cytotoxic drugs were excluded. In parallel with each RA sample leucocytes were obtained from an ageand sex-matched volunteer control subject.

\section{LEUCOCYTE MIGRATION INHIBITION TEST (LMT)}

The LMT assay was performed as described by Bendixen and Søborg ${ }^{16}$ with minor modifications. Leucocytes obtained from heparinised peripheral blood by sedimentation at $37^{\circ} \mathrm{C}$ for 60 minutes, were washed 3 times with HBSS, adjusted to $4 \times 10^{7}$ cells $/ \mathrm{ml}$, and packed into precision capillary tubes (Drummond Scientific Co., Broomall, Pennsylvania, USA). The cells were then allowed to migrate into wells (Sterilin) containing Eagles medium supplemented with $12 \%$ horse serum, $80 \mathrm{IU} / \mathrm{ml}$ penicillin and $80 \mu \mathrm{g} / \mathrm{ml}$ streptomycin.

Assays were performed on matched RA and control cells at the same time using the same antigen preparations. Quadruplicate assays for each patient at each antigen concentration were set up and read 'blind'. Control migrations without antigen were performed on each plate. After 21 hours' incubation at $37^{\circ} \mathrm{C}$ the areas of migration were measured by planimetry and results were expressed as a migration index (MI) where:

$$
\mathrm{MI}=\frac{\begin{array}{c}
\text { mean migration area in presence of } \\
\text { antigen }
\end{array}}{\begin{array}{c}
\text { mean migration area in absence of } \\
\text { antigen }
\end{array}} \times 100
$$

Replicate migrations showed less than $10 \%$ variation between wells. Groups of data were compared using the Student's $t$ test.

\section{Results}

\section{SYNOVIAL HOMOGENATES}

Crude low spin homogenates of 8 rheumatoid synovia were assayed at 3-5 concentrations in the LMT using cells from a total of 49 pairs of rheumatoid and control subjects. All the samples tested yielded inhibitory material at concentrations of protein above $200 \mu \mathrm{g} / \mathrm{ml}$. However, none of these preparations produced specific inhibition of rheumatoid cells, being equally inhibitory for both RA and control leucocytes. This overall result is illustrated in Fig. 1A, using homogenate obtained from patient 12 (Table 1). Initial attempts to characterise the inhibitory material in the crude tissue homogenate involved centrifugation at high speed to remove membrane fragments. This procedure completely removed the inhibitory material in all 5 samples tested. Thus the high spin supernatant from the case 12 homogenate showed no inhibitory activity in the LMT, even at protein concentrations of $500 \mu \mathrm{g} / \mathrm{ml}$ (Fig. 1B).
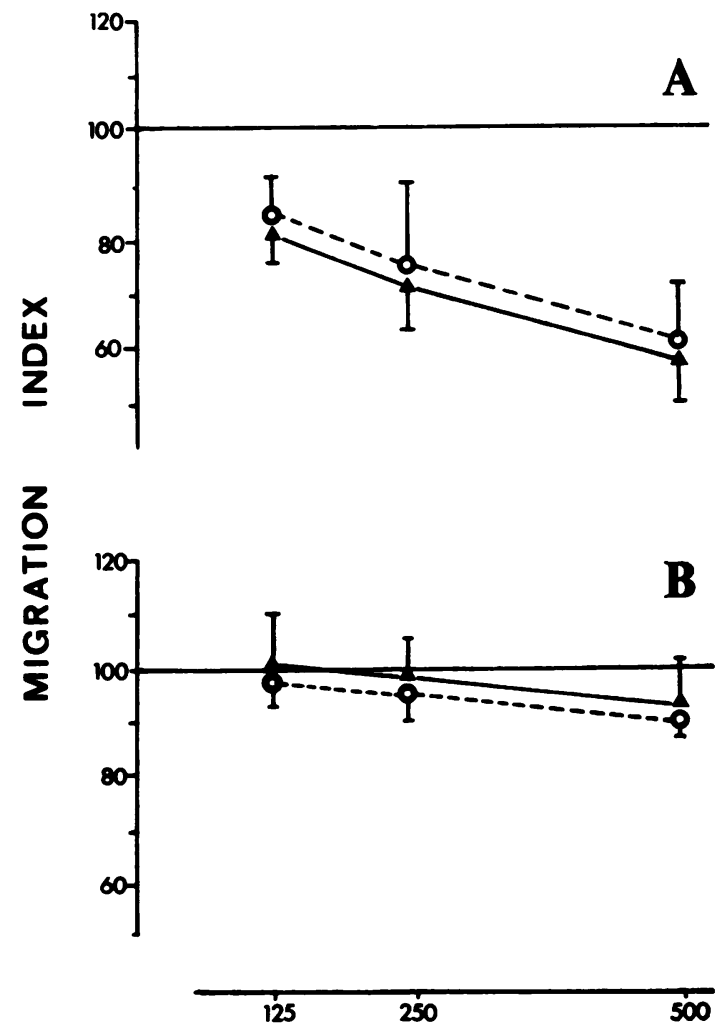

PROTEN CONCENTRATION $(\mu \mathrm{m} / \mathrm{mll})$

Fig. 1 The effect of $(A)$ low spin homogenate and $(B)$ high spin homogenate on leucocyte migration. The homogenates were prepared from a rheumatoid synovium (patient 12 in Table 1) and were assayed in the LMT at 3 protein concentrations. The graphs show the mean migration index \pm 1 standard deviation of 4 experiments (rheumatoid leucocytes $\Delta-\Delta$, control leucocytes 0- -0). 


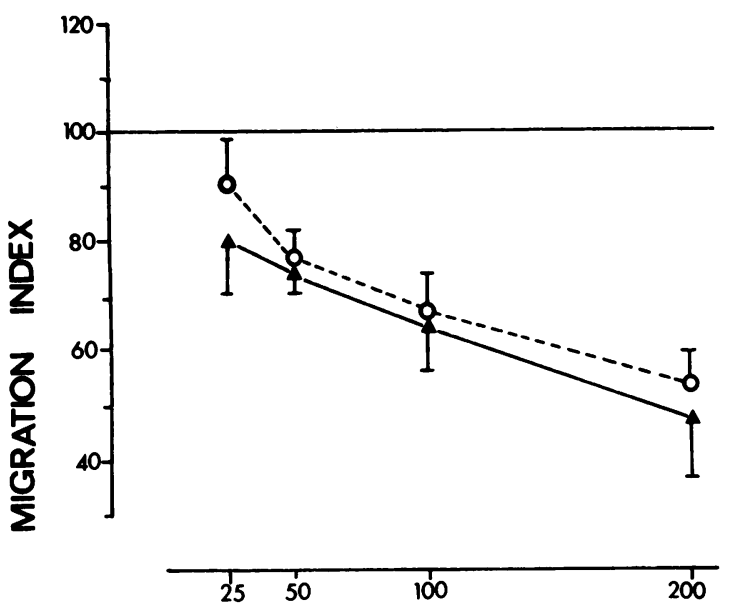

PROTEIN CONCENTRATION $(\mu \mathrm{g} / \mathrm{ml})$

Fig. 2 The effect of synovial eluate on leucocyte migration. The eluate was prepared from a rheumatoid synovium (patient 13 in Table 1) and was assayed in the LMT at 4 protein concentrations. The graphs show the mean migration index \pm 1 standard deviation of eleven experiments $(R A$ leucocytes $\Delta-\Lambda$, control leucocytes $\mathbf{0}-\mathbf{0}$ ).

\section{SYNOVIAL ELUATES}

EDTA-mercaptoethanol extracts of synovial tissue caused migration inhibition when assayed in the LMT. Eluates from 8 synovia were assayed at 3-5 protein concentrations in the LMT with leucocytes from 67 pairs of rheumatoid and control subjects. $\overrightarrow{\vec{B}}$ Data from a representative sample (patient 13 in Table 1) is shown in Fig. 2. This illustrates that inhibitory material is concentrated in the solubilised extract since the addition of protein at concentrations above $50 \mu \mathrm{g} / \mathrm{ml}$ caused significant inhibition of both RA and control cells. This is in contrast to on the $200 \mu \mathrm{g} / \mathrm{ml}$ of crude homogenate protein required $\vec{\circ}$ to produce the same effect. The inhibitory material in the eluate was not removed by ultracentrifugation at $100000 \mathrm{~g}$ for 1 hour. In 5 cases (4RA, 1AS) the synovial eluate caused nonspecific inhibition of rheumatoid and control cells in the LMT. One rheumatoid eluate (patient 18 in Table 1) specifically inhibited rheumatoid leucocyte migration at a protein concentration of $50 \mu \mathrm{g} / \mathrm{ml} \quad(\mathrm{P}<0.01)$. However, another subject (patient 16 in Table 1) yielded a synovial eluate which was more inhibitory for control leucocytes than for RA cells $(P<0 \cdot 01)$. Synovial eluate from the patient with PVS (patient 22 in Table 1) was not inhibitory in the LMT even at a protein concentration of $1600 \mu \mathrm{g} / \mathrm{ml}$.

\section{GEL FILTRATION STUDIES OF}

SYNOVIAL ELUATES

Attempts were made to characterise the inhibitory material contained in the synovial eluate. Eluates from 13 rheumatoid synovia were fractionated by gel filtration on Ultragel AcA22. Pooled fractions were assayed in the LMT with leucocytes from 41 pairs of RA and control subjects. Analysis of the active material from patient 13 in Table 1 (Fig. 2). resulted in the elution profile shown in Fig. 3. Six fractions from this column were concentrated and

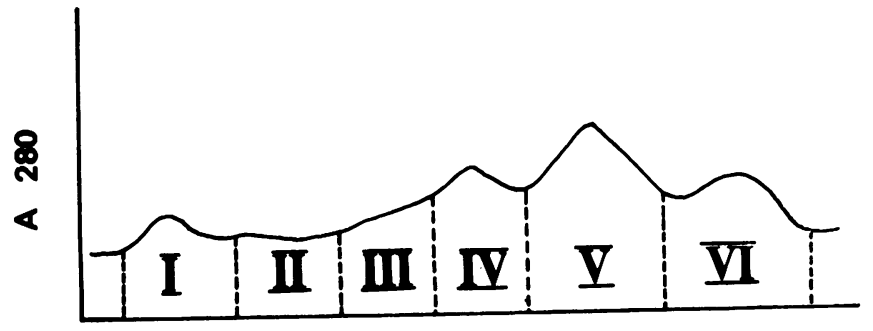

ELUTION VOLUME

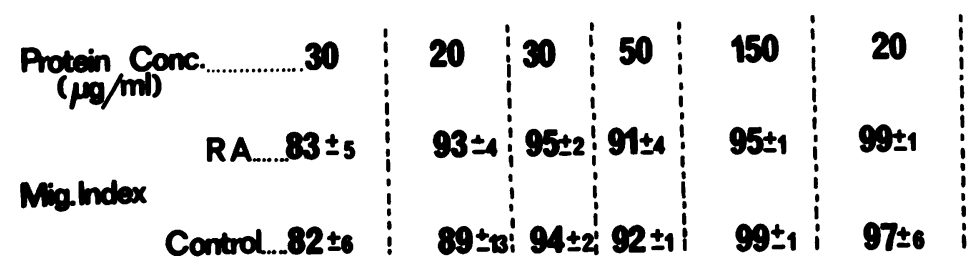

Fig. 3 Gel filtration analysis of rheumatoid synovial eluate (patient 13 in Table 1) on Ultragel AcA22. Six fractions were pooled, concentrated, and assayed immediately in the LMT at the protein concentrations indicated. The migration index values are the mean \pm 1 standard deviation for rheumatoid $(n=2)$ and control $(n=2)$ leucocytes. 
assayed in the LMT. As shown in Fig. 3, the inhibitory material was found in the void-volume (fraction 1 ), which corresponds to a molecular weight of at least $10^{6}$ daltons.

\section{Discussion}

The experiments described in this paper were performed in order to collect in a single laboratory extensive data on the interaction between rheumatoid leucocytes and rheumatoid synovial tissue extracts, and thus to clarify the role of putative synovial membrane antigens in the pathogenesis of rheumatoid arthritis. Therefore, a large number of synovia (22) were analysed and assayed in the LMT over a range of protein concentrations against a total of 157 matched pairs of rheumatoid and control leucocytes. These results constitute a much larger set of data than has been obtained in previous studies.

All 20 rheumatoid synovia yielded inhibitory material as assayed in the LMT, as did the sample from a patient with ankylosing spondylitis. In contrast, inhibitory material could not be extracted from the synovium of a patient with pigmented villonodular synovitis. This may indicate that the inhibitory material is associated with the inflammatory process. In general, this inhibitory factor showed no specificity towards rheumatoid leucocytes, being equally active against both RA and control cells in the LMT. However, occasional individual samples did yield extracts which caused 'specific' migration inhibition restricted to either rheumatoid or control leucocytes. These results may partly explain the conflicting data in the literature, since much of this was obtained from synovial preparations from single donors only.

Further studies have been carried out to characterise the inhibitory material in the synovial homogenates. Results from ultracentrifugation experiments indicated that this inhibition was associated with membrane fragments. This suggests that the inhibition of leucocyte migration may be a consequence of phagocytosis of these particles. This process is known to induce inhibition of leucocyte migration from capillary tubes. ${ }^{17}$ Such a conclusion casts doubt on the 'antigenicity' of crude synovial tissue homogenates in the LMT. However, the active factor may be solubilised from synovial membrane by extraction with EDTA-mercaptoethanol. ${ }^{14}$ Such eluates were inhibitory in the LMT at lower concentrations than were the homogenates.

The inhibitory factor, although not sedimented by high speed centrifugation was found to have a high molecular weight (greater than $10^{6}$ daltons). It is possible that phagocytosis of this material was responsible for its inhibitory effect on leucocyte migration. Attempts have not been made to characterise the factor further. A number of large molecules, including immune complexes and fibrinogen/fibrin, are found in association with chronic inflammation. However, immune complexes have been shown to produce specific migration inhibition of rheumatoid leucocytes $^{18}$ rather than the nonspecific effects observed with synovial eluates. In addition, stepwise elution of RA synovial membrane has demonstrated that the material active in the LMT is not found in those fractions associated with immune complexes. ${ }^{8}$ Fibrinogen has been shown to cause nonspecific inhibition of leucocyte migration at protein concentrations as low as $10 \mu \mathrm{g} / \mathrm{ml}$ (Hall and Morgan, unpublished observations). This effect is unlikely to represent an immunological reaction but is probably due to the physical trapping of leucocytes in a mesh of fibrinogen/fibrin molecules. Other large masses of protein resulting from partial degradation of protein by proteases present in inflammatory sites and subsequent aggregation may also form part of the inhibitory material isolated from inflamed synovia. Proteases themselves, although able to show MIF-like properties, ${ }^{19}$ are generally small molecules and so are unlikely to beresponsible for the high molecular weight inhibitor of leucocyte migration described in this study.

In conclusion, this study provides no evidence for the existence of antigenic material in rheumatoid synovial membrane responsible for promoting a specific immune response. The large nonspecific inhibitor isolated from inflamed synovial tissue may, through its interaction with phagocytic cells, play some role in maintaining chronic inflammation. It should be emphasised that the leucocyte migration inhibition test does not allow the identification of all potential antigens in a complex tissue such as rheumatoid synovium. For example a sensitive radioimmunoassay can detect small quantities of carcinoembryonic antigen (CEA) in synovial tissue from RA patients. ${ }^{20}$ However, a role for such minute amounts of antigen in the immunopathogenesis of rheumatoid arthritis has yet to be established.

This work was supported by a grant from the Arthritis and Rheumatism Council for research.

\section{References}

1 Zvaifler N J. The immunopathology of joint inflammation in rheumatoid arthritis. Adv Immunol 1973; 16: 265-336.

2 Smiley J D, Sachs C, Ziff M. In vitro synthesis of immunoglobulin by rheumatoid synovial membrane. J Clin Invest 1968; 47: 624-632.

3 Stastny P, Rosenthal M, Andreis M, Ziff M. Lymphokines in the rheumatoid joint. Arthritis Rheum 1975; 18: $237-243$. 
4 Paulus H E, Machleder H I, Levine S, Yu D T Y, MacDonald N S. Lymphocyte involvement in rheumatoid arthritis: Studies during thoracic duct drainage. Arthritis Rheum 1977; 20: 1249-1262.

5 Marmion B P. Infection, autoimmunity and rheumatoid arthritis. Clin Rheum Dis 1978; 4: 565-586.

6 Rothenberger W, Thiele H G. In vitro-studie zur Pathogenese der primär chronischen Polyarthritis mittels des Migrationsinhibitionstest. Klin Wochenschr 1970; 48: 1308-1311.

7 Rothenberger W, Thiele H G. In vitro-studie zur Pathogenese der primar chronischen Polyarthritis mittels des lymphocytentransformationstests. Klin Wochenschr 1970; 48: 518-521.

8 Bacon P A, Bluestone R, Cracchiolo A, Goldberg L S. Cell-mediated immunity to synovial antigens in rheumatoid arthritis. Lancet 1973 ; 2: 699-702.

9 Thonar E J-M A, Sweet M B E. Cellular hypersensitivity in rheumatoid arthritis, ankylosing spondylitis and anterior nongranulomatous uveitis. Arthritis Rheum 1976; 19: 539-544.

10 Kahan A, Alcalay M, Amor B, Delbarre F. Study of cellular immunity in rheumatoid arthritis. Inhibition of leucocyte migration by a synovial extract. Biomedicine 1975; 23: 111-115.

11 Landsbury J, Allen G E, Rogers F B. Failure of skintesting to detect antigen-antibody properties in the tissues of rheumatoid arthritis. Am J Med Sci 1955; 229: 191-192.

12 Braunsteiner H, Eibl M, Follinger K. Allergie vom verzögerten Typ gegenuber gelenkextrakten bei Patienten mit primär chronischer Polyarthritis. Wien $Z$ Inn Med Grenz 1961; 42: 530.

13 Multz C V, Kamin E J, McDowell M K, Butler B. Delayed dermal reactions to homogenised synovial tissue. Arthritis Rheum 1968; 11: 110 (abstract).

14 Marchesi S L, Steers E, Marchesi V T, Tillack T W. Physical and chemical properties of a protein isolated from red cell membranes. Biochemistry 1970; 9: 50-57.

15 Lowry O H, Rosebrough N J, Farr A L, Randall R J. Protein measurement with the Folin phenol reagent. $J$ Biol Chem 1951; 193: 265-275.

16 Bendixen G, Søborg M. A leucocyte migration technique for in vitro detection of cellular (delayed type) hypersensitivity in man. Dan Med Bull 1969; 16: 1-6.

17 Bryant R E, DesPrez R M, VanWay M H, Rogers D E. Studies on human leucocyte motility. I. Effects of alteration of $\mathrm{pH}$, electrolyte concentration and phagocytosis on leucocyte migration, adhesiveness and aggregation. J Exp Med 1966; 124: 483-499.

18 Hall N D. Leucocyte migration inhibition with IgG-IgG complexes and rabbit IgG fragments in patients with rheumatoid arthritis. Clin Exp Immunol 1978; 34: 219225.

19 Geiger C, Vischer T L. Migration inhibition factor-like activity in inflammatory synovial fluids might be due to proteases. Clin Exp Immunol 1976; 26: 176-180.

20 Unger A, Panayi G S, Tidman N H. Comparative study of carcinoembryonic antigen in rheumatoid synovium, tumour and normal adult lung. Ann Rheum Dis 1977; 36: 66-70. 